\title{
NARRATIVE OF THE UNCONSCIOUS AND SUBLIME
}

\section{SAMIRA SINHA}

Jagannath Nagar College, Ranchi University, Ranchi

The origins of literature in areas as diverse as the Far East, East, Middle East, Mediterranean, Europe, America and Africa is seeded in a great body of oral histories' myths, creation myths and legends, many of which were subsequently put into written form. They preserve a vast reservoir which is drawn on by writers since the emergence of literary culture in various parts of the world.
\end{abstract}

KEYWORDS: East, Myths \& Reservoir

Received: Oct 08, 2018; Accepted: Oct 28, 2018; Published: Nov 12, 2018; Paper Id.: IJELDEC20188

\section{INTRODUCTION}

What, after all is a myth? This word is defined in many ways but most prominently it originates from the Greek term 'mythos', which means 'word' or 'story'. Another word, 'logos', was later added by the Greeks which means 'word of truth'. Since then 'logos' is commonly used with reference to 'true' stories, for instance facts of historical accounts, while the term 'mythos' refers to stories passed down orally through generations, quite often with additions by story tellers which were later transcribed into letters. In other words 'mythos' evolved into the generic form called fiction.

Fiction, as we all know, serves many purposes, as for example, entertainment, or a means of preserving origin myths. It also acts as an expression of culture of various societies describing their traditions and ideas. These stories exercise immense power over people's imagination and aspirations, as they constitute a corpus of ideas giving different people their several myths through which they are able to define themselves and establish an identity in a distinct manner. However the boundaries of all literature are porous through which exchange of ideas as well as narratives permeate and commute. For instance, the Bible acts as the root for Western history and literature. Often they are a fall out of trade or colonialism, for example the construct of the 'other' through crusade narratives. Migrating people also brought myths along with them, stories of their homeland and integrated them with those of the adopted country. The ability to absorb and integrate literary influences is what defines the world as a cultural region. (Anderson et. al., 2010) Thus deities and their stories across cultures have common elements resulting in the constructs of archetypes, bipolar aspects, journeys, quests and the deluvian.

Myths, whether believed as truth or simply enjoyed as stories, always have an almost magical appeal. Philosophers too, as early as the seventeenth century were fascinated with similar themes and characters as can be observed from various tales in the world. Furthermore, Europeans initially held that myths were nothing more than strangely distorted Bible stories. Another perspective is that they are primitive or symbolic efforts to explain natural phenomena. James Frazer, a British anthropologist, for example, proposed that myths show how the welfare of each society depends on how well its king ruled. (Frazer, 1850) 
In the twentieth century scientists, philosophers and anthropologists began to explore the human mind and psyche to find answers to the question as to why myths were created and are still of abiding importance. Sigmund Freud, the Austrian psychoanalyst, worked on the hypothesis that myths are the actualization of people's frightening unconscious fears and urges. It magnanimously provides a non threatening method to people in dealing with them. As an example he has quoted the Greek myth of Oedipus, who unknowingly killed his father and married his mother. He proposed that this myth symbolizes a stage which all boys undergo when they feel hostility towards their father and attraction towards their mother. (Freud, 1931: vol. XXI)

Carl Jung, another psychoanalyst, has observed that myths have a powerful hold over human imagination because of the fact that they contain archetypes or principal symbolic characters which are nascent to every human psyche or unconscious. As myths depict the universal archetypes, they evidently help in working out individual conflicts in society. (Moonchild, Kindle Edition) Some archetypical characters like the Wise Old Man, the Good Loving Mother, the Fool, the Evil Giant/ Monster, the Kind and the Miserly, for example, are prevalent in myths throughout literature, but perhaps the most powerful of all is that of the Hero.

Myths and legends in any culture weave tales of extraordinary individuals who resist all odds and do good for society by performing superhuman feats. Usually, though not always, they have supernatural strength, even magical powers. Sometimes they may be half mortal and half god, like Heracles, whose father was the Greek god Zeus and whose mother was a mortal. Bheeshm in the epic, Mahabhatrat, was born of the goddess Ganga and a mortal father. Even the Pandavs- Yudhishthir, Karna, Arjun and Bhim, with different gods as their fathers had a common mother, Kunti, who was a mortal. Perseus, like other great heroes, risked a fate worse than death when he set out to strike off the head of the hideous gorgon, Medusa. Some heroes, who are gods themselves, defy the immortals to help mankind, such as Prometheus, who stole fire from heaven to benefit mortals and he was savagely punished by Zeus for this act of defiance. In Indian mythology too we come across many incarnations of Vishnu, who fought other powerful mortals for the salvation of mankind, like Ram's battle against Ravana, and Krishna's killing of Kansa, which stand out as some of the most famous episodes. (Even Durga's battle against the Demons can be considered in the category of creation myth of the warrior goddess and can be studied as the subject matter for another thesis, for that, as they say, is another story.)

There have been cultural heroes too who perform a number of different roles. Traditional warrior heroes like Gilamesh of Mesopotamia and the Anglo- Saxon, Beowulf, hero kings such as Theseus and Arthur the Great, Ashoka and Chandragupta, who are legends in themselves, tragic heroic lovers such as Sigmund and Brynhild and the unlikely, often reluctant common heroes such as Alladin and Robin Hood, who are but a few examples of cultural heroes. Heroic characters such as these abound in the rich collection of myths and heroic literature across cultures. The Iliad in Greece, Mesopotamia's Epic of Gilamesh, Mexico's Popl Vuh, the Anglo- Saxon Beowulf, the Native American Spider Woman tales, Persia's Arabian Nights, India's Ramayana and Mahabharata, to name a few, constitute a rich reservoir of heroic literature from which a myriad other stories take inspiration. The heroes of Indian mythology perhaps predate other recorded heroes of the West. Some, regarded as deities, such as Ram and Krishna, set high standards of moral conduct to which the people could aspire. Arjun, Duryodhan, Karna and Bhim are also associated with many heroic tales.

Heroic myths, no matter what their provenance, have in many instances elements in common. These are a call to adventure, a long dangerous voyage or search, the overcoming of formidable trials, slaying of enemies or deadly, grotesque monsters and the rescue of the poor and helpless. All these elements make for exciting and captivating stories. But 
traditional heroes also have their not so admirable characteristics which is solely dependent on culture. For instance in ancient Greece heroes were worshipped for their strength, athletic ability, skill with weapons and actions that were beneficial to their community. But, on the contrary, expectations of moral or ethical values were absent. The term hero was also used for a homicidal boxer like Cleomedes of Astypalia in Greece. When he was disqualified for accidentally killing his opponent in the Olympic Games, he became so angry that he smashed a school building on top of sixty children, and yet he is considered a hero. Heracles is portrayed as a glutton, a womanizer, rapist and drunkard, and as having brutal outbursts of rage, yet he is considered as a Greek hero. Gilamesh, an ancient king of Uruk in Babylonia, is well known for his feats of superhuman strength as well as for his womanizing. The bravery of Duryodhan is never in doubt despite his many faults. Karna and Bheeshm and other stalwart warriors are venerated despite the fact that they sided with Duryodhan. Vanity, gluttony, avarice and lust and other such drawbacks humanize the heroic characters, whose exemplary heights would otherwise be an impossible aspiration for the common man.

Even Shakespeare's gamut of 'flawed' heroes is legendary, having universal appeal. In the opinion of Harold Bloom expressed in his book Shakespeare: The Invention of the Human (1998) Shakespeare's genius lay not in characterization but in the creation of the human as we never would have imagined they were and they help us to understand ourselves better. As Dr. Johnson has said: "Imitations produce pain or pleasure, not because they are mistaken for realities, but because they bring realities to mind”. (1998:2). Shakespeare invented ways of representing human change which is why his characters remain alive even today after more than four hundred years of their creation. This he managed to do by making them masters of their own destiny or fate. For instance Hamlet is set free by the knowledge of the unspeakable and he denounces himself as one who "Must like a whore unpack my heart with words". His tortured soul can give words to it only through drama. Hamlet dies a free man, but when Macbeth dies, although it is proclaimed that "The time is free", we hardly feel free of the reverberations of the horror of Macbeth's imagination. For Macbeth we have nothing but pity- pity for what he could have risen to be but what he ultimately degraded himself to become.

The heroes of modern fiction, on the other hand are, what one may call, 'god of small things', to borrow, for instance, the title of the Booker Prize novel The God of Small Things written by Arundhati Roy. Although they cannot boast of superhuman qualities, their strength of character in the face of challenges give rise to heroic moments that are uplifting and motivating for the reader while also raising the stature of the character to that of a hero. They display exemplary qualities of endurance, courage, cleverness and intelligence in the face of difficulties and extreme adversity. On these lines I seek to explore three such fictional characters who are diverse in their origins, circumstances and lore, yet conform in many ways the aspects of an archetypal hero. They are, Kalo from Bhabani Bhattacharya's novel He Who Rides a Tiger, Velutha from The God of Small Things written by Arundhati Roy and Eklavya from Shashi Tharoor's book The Great Indian Novel.

Kalo, a blacksmith from a village, Jharna, in Bengal is a simple, robust rustic who leads a happy life with his adorably beautiful and intelligent daughter, Chandralekha. She brings fond memories of his late wife. They lead a contented life until a great famine strikes Bengal reducing the tillers, weavers and tradesmen to a state of starvation. An exodus begins thereafter compelling entire masses to migrate towards the big cities in search of employment and food. Kalo's journey from Jharna to Calcutta is a saga of dehumanizing experiences. He is arrested for stealing bananas and from a self- respecting, self- sufficient tradesman he is reduced into a number in prison. His anger towards the apathy and indifference of the administration and society reaches a climax while he saves his daughter, Chandralekha from being 
defiled in a brothel. He proceeds on a quest for revenge against the corrupt rich and hypocritical society by successfully metamorphosing into Mangal Adhikari, the priest.

Although by birth he is of low caste who would, under the norms of religious practices, not be allowed to enter the temple, but in the guise of Mangal Adhikari he presides over the temple, while the rich and the high caste touch his feet for blessings and seek his advice on various issues. Kalo remains true to his trade, practicing his craft in secrecy, but gradually, with the passage of time he becomes smitten by his conscience. He feels guilty about taking the hard earned money of the poor devotees who even during hard times, made offerings at the temple. When people offered milk on the idol of Shiva, oblivious to the cries of starving children, Kalo strikes a humane posture and instructs his faithful aide and fellow blacksmith, Vishwanath, to collect the milk offerings, boil it, and to distribute it among the poor, starving children. This is later discovered and strongly objected to by the rich devotees.

Kalo finally gathers courage and decides to dismount the tiger of charltanism on which he rode to avenge the treatment meted out to him, when the greedy and lecherous businessman, Motichand, already married twice, proposed to make Chandralekha the Goddess of the seven- fold bliss and marry her. One requires supreme courage to take on the wrath of the rich, the high and mighty by disclosing the truth about the myth he had created to befool them, obliging them to worship a false god. He shattered the caste barrier laying bare the untruth that the wrath of gods would visit upon him if he did so. Ultimately he becomes the emancipator of the downtrodden. Biten, the Brahmin youth who threw off his nine- stranded thread and proposed to marry Chandralekha, and observes: "The blacksmith's story is a legend of freedom, a legend to inspire and awaken" (Bhattacharya, 1955)

As Kalo is carried off on the shoulders of the masses we become enarmoured of a hero who has risen above all circumstances, and brings about a qualitative change in the lives he touches. He uplifts the downtrodden inspiring them to be courageous enough to transform their fate. His esteem in the eyes of the witness is enhanced with respect to his merit and human qualities.

In The God of Small Things written by Arundhati Roy Velutha, an outcaste has a special mention. This untouchable Paravan is venerated and honoured by the upper caste twins Rahel and Estha, and their mother, Ammu. Although Velutha's grandfather along with other untouchables had converted to Christianity in an attempt to escape the scourge of untouchability they were unsuccessful. Velutha, a gifted carpenter, was a regular visitor of Aymennem House since childhood. Mammachi, Ammu's mother once remarked that “if only he hadn't been a Paravan, he might have become an engineer." (Roy, 1997) She later made him incharge of the general maintenance of her pickle factory, where he was resented against by other 'touchable' workers. A self made man and an excellent professional, his aspirations were high. Velutha's life's ambition was to change the existing social order. He became a follower of communism and was actively involved in the programmes of the Communist Party.

He loved the twins Rahel and Estha dearly and their divorcee mother, Ammu as well. Both Ammu and her children reciprocated his love and caring nature. For them he stood tall in estimation due to his qualities as a human being, almost to the extent of reverence. This became his nemesis, since he had aspired to have a relationship with an upper caste woman, for which he suffered unbearable humiliation at the hands of Mammachi. None came to his rescue while he was mercilessly tortured to death by the police for no legitimate reason, not even the party to which he had pledged allegiance. The twins, whom he loved ardently, and who loved him in return, remained silent witnesses to his suffering. Velutha, one of the best drawn characters of Arundhati Roy's novel The God of Small Things emerges bravely as a tragic hero who, 
despite having the disadvantages of his lowly social stature, shines above the rest of the characters because of his super human qualities and strength. James George Frazer, a Scottish social anthropologist, writes in his book The Golden Bough: A Study in Magic and Religion: “...strength of character in the race as well as in the individual consists mainly in the power of sacrificing the present for the future, of disregarding the immediate temptations of ephemeral pleasure for more distant and lasting sources of satisfaction. The more the power is exercised the higher and stronger becomes the character: till the height of heroism is reached in men who renounce the pleasures of life and even life itself for the sake of winning for others, perhaps in distant ages, the blessings of freedom and truth.” (Frazer, 1850: Vol. I)

Shashi Tharoor, it may be observed, in his fictional work The Great Indian Novel (1989) merges myth with history. He revisits the mythical epic of Mahabharat written by Ved Vyas with the help of which he provides an insight into the world of politics in contemporary India. By using the ancient technique of narration his storytelling apparently comes from many narrators although there is but one narrator. The novel provides a dedoxification of mythology. The term 'doxa' means a commonly held opinion. The commonly held opinion about the characters of Mahabharat is turned upside down to emphasise the human flaws inherent within them. Each character taken out of the Mahabharat has a satirized modern equivalent, while Draupadi is personified as democracy. But the emphasis is on the character of Eklavya, who is a representative of the Dalit class. He is the son of a Nishad (a low caste) and in the Mahabharat he could not be trained as a warrior under the tutelage of the guru Dronacharya for the simple reason that he was born of a low caste. He then made an image of Dronacharya and regarding him as his guru meticulously continued to practice archery all by himself. When at an opportune moment, he shot the 'Shabdabhedi' arrow to silence the wild dogs disturbing the religious 'yagya', a feat which the Pandavas, Kauravas and their Guru were unable to accomplish; they became conscious of the supremacy of Eklavya over Arjun whose claim of being the best archer could be jeopardized. Guru Dronacharya on learning from Eklavya about the practice of his skill asked him to sacrifice his thumb and offer it as fees or 'gurudakshina' to his Guru, a teacher in absentia, thus removing Arjun's strongest competitor forever.

Tharoor in his novel creates Eklavya, a poor boy who studies in a government school and performs better than Arjun who has a private tutor named Drona. Eklavya evesdrops on his tuition classes and regards Drona as his guru. When Drona learns about the truth, how he gained knowledge and is able to perform better than Arjun, he demands Eklavya's thumb as his fees because he has trespassed a territory where he did not belong. But Tharoor's Eklavya is defiant and even aggressive. He blatantly refuses to pay the fees demanded by the preceptor and replies: "Without my... thumb, I won't be able to write again." (Tharoor, 1993)

At this point Eklavya in his modern 'avtar' rises above his subaltern status as he becomes conscious of a new sense of equality and power to combat the hegemony of the rich and powerful. Equipped with a new sense of identity he stands out as a hero of the modern world. The three characters under study, that is, Kalo, Velutha and Eklavya, step beyond the boundaries set by society and this constitutes a heroic act. They have the ability to stand above the crowd and break free from its shackles.

In the process of studying myth and fiction, past and present, a common link that we come across between all cultures is that of the figure of the hero. In the ancient myths we see the hero perform extraordinary feats of bravery, risking his life while facing the hazards of fantastic journeys, and displaying by example a sustained way of life for the benefit of all humans. Along their journey they often come across fantastic creatures and people, obstacles which they refuse to succumb to and they perform feats of power, sometimes miraculous and accomplish their goals. Their adventures 
have been told and retold much beyond the limits where cultures have grown and changed. The hero of modern fiction has his heroic moment too, the one moment of life which defines him as he rises above the ordinary, resisting all adversities and achieves glory to establish the moment of truth.

Joseph Campbell, a noted scholar and popular mythologist, who spent a lifetime studying and comparing the hero myths of different cultures, writes in his book The Hero With a Thousand Faces: "A legendary hero is usually the founder of something - the founder of a new age, the founder of a new religion, the founder of a new city, the founder of a new way of life. In order to found something new, one has to leave the old and go in quest of the seed idea, a germinal idea that will have the potentiality of bringing forth that new thing." (2008; first pub. 1947) In the novel He Who Rides a Tiger, Kalo exposes the hypocrisy and inhumanity of a system that brands a person inferior by birth and not by deed. In The God of Small Things, Velutha's passive resistance and ultimate death highlights the decay of Ayemennem House and brings it center stage. In The Great Indian Novel the subaltern finally resists social norms to defend his action and in turn upgrades his status in society. All three are heroes of their microcosmic world of unequal opportunities. While Velutha exposes the rot, Kalo shows the way to emancipation and Eklavya establishes a new found identity of equality and power. The superheroes of Myths have no real need or obligation to act as they do. But the underdog in modern fiction has to work extremely hard to be a hero.

While history helps us to visualize what has happened in the world, literature helps us to envision what is possible. It takes us a step further to feel pain, both real and imagined, and in doing so to be human. If we were to ponder over the question, 'Why Hero?' then the answer would perhaps be 'What else?' Whether we consider a myth or a legend, a story or a folk tale, a drama or a film and sometimes even a poem - the hero becomes the pivot around whom the story rotates and unfolds. They inspire awe and admiration, even love, and the persona created strikes within us a strong chord. They shake us out of the passive, ordinary and humdrum, people our imagination, embark on an impossible quest, to make us believe in ourselves that we too can make the impossible possible.

Hero myths, therefore, have a universal and eternal appeal because they relate stories of fantastic adventure, filled with narrow escapes, bloody battles, buried treasures, and in which good always triumphs over evil. The narrative moves from the known to the unknown and concludes in victory against all odds. Although the journey is always a personal one for the hero, his achievements are always shared by his community. Kalo's journey from self- negation to self- assertion is a case in point. Taken to a deeper level of consciousness or symbolic level, the hero's journey reflects our passage through life, which incidentally each one of us is compelled to experience, in order to transcend to a higher, spiritual level. Whether personal or cosmic, the hero walks the razor's edge, and his quest is that of self- discovery.

\section{CONCLUSIONS}

Finally, stories about heroes connect us with our deepest humanity. They make us aspire towards altruism reminding us of who we are and what we can be. The hero's journey represents our collective growth as a community as well as the spiritual growth of mankind wherein lies the eternal appeal of the hero. Everyday heroes demonstrate irrefutably that the logic and deeds of myth survive in these modern times, waiting for the traffic light to change, perhaps to rescue little children and protect the old from harm while crossing the road. Reverend Otis Moss, jr. in the Preface to Why Good Things Happen to Good People written by Stephen G. Post and Jill Neimark cites the example of Sister Leola McNair, who was not afraid or defeated when she was told that both her legs would have to be amputated. Instead, she told the Reverend, she was thinking of all the wonderful things she could or would do with her hands. In this context he draws 
attention to the symbolism of the desert and the rose mentioned in the Book of Isaiah, Chapter 35, Verse I: "The desert shall rejoice and blossom like a rose". Life brings many desert experiences where we delve into a spiritual well and pull up the courage to plant a rose in the desert, balancing the unconscious and the sublime.

\section{REFERENCES}

1. Bhattacharya, Bhabani. He Who Rides a Tiger. An Orient Paperback, Delhi: Hind Pocket Books (P) Ltd., 1955. Print.

2. Bloom, Harold. Shakespeare: The Invention of the Human. London: Fourth Estate Limited, 1998. Print.

3. Campbell, Joseph. The Hero With a Thousand Faces (The Collected Works of Joseph Campbell). Canada: New World Library, 2008. ( First Published 1947 by Bollingen Foundation: Pantheon Books) Print.

4. Ed. Daniel Anderson et. al. The Story of Literature- From Antiquity to the Present. Potsdam, Germany: h. f. ullmann publishing, 2010. Print.

5. Frazer, James George. The Golden Bough: A Study in Magic and Religion. Vol. I, 1850.(c) Goodread, Inc. Terms: Desktop version.

6. Freud, Sigmund. The Complete Psychological Works of Sigmund Freud, London, 1931, Vol. XXI.

7. Jaydipsinh Dodiya and Joya Chakravarty Ed.. The Critical Studies of Arundhati Roy's 'God of Small Things'. New Delhi: Atlantic Publishers and Distributors, 2001. Print.

8. Mohit K. Ray Ed.. Indian Writing in English. New Delhi: Atlantic Publishers and Distributors (P) Ltd., (2003) 2008. Print.

9. Moonchild, Meredith. An Introduction into the World of Carl Jung: The Shadow, The Archetypes and The Symbols. Kindle Edition.

10. Post, Stephan G. and Jill Neimark. Why Good Things Happen to Good People. New York: Broadway Books (Harmony 2008).Print.

11. Press, Petra. Great Heroes of Mythology. New York: Metro Books (an imprint of Friedman/ Fairfax Publishers), 1997. Print.

12. Rai, G. Bhabani Bhattacharya: A Study of his Novels. Delhi: B. R. Publishing Corporation, 1995. Print.

13. Roy, Arundhati. The God of Small Things. New Delhi: IndiaInk Publishing Co. Pvt. Ltd., 1997. Print.

14. Shimmer, Dorothy B. Bhabani Bhattacharya. Boston: Twayne Publishers, 1975. Print.

15. Tharoor, Shashi. The Great Indian Novel. New Delhi: Arcade Publishing, (1989) 1993. Print. 
